\title{
Relationship Between Level of Milk Production and Multiple Ovulations in Lactating Dairy Cows*
}

\author{
H. Lopez, ${ }^{1}$ D. Z. Caraviello, ${ }^{1}$ L. D. Satter, ${ }^{1,2}$ P. M. Fricke, ${ }^{1}$ and M. C. Wiltbank ${ }^{1}$ \\ ${ }^{1}$ Department of Dairy Science, University of Wisconsin, Madison 53706 \\ ${ }^{2}$ U.S. Dairy Forage Research Center, USDA-Agricultural Research Service, Madison, WI 53706
}

\begin{abstract}
Our objective was to evaluate factors associated with spontaneous multiple ovulations in lactating dairy cows. Ovaries of cows [ $\mathrm{n}=267 ;>50$ days in milk (DIM)] were evaluated weekly using ultrasound to determine spontaneous (i.e., no hormonal treatment) ovulation rate starting at $50 \mathrm{DIM}$ and continuing until pregnancy diagnosis. Cows were fitted with a transmitter to record standing activity during estrus, and serum progesterone concentration was assessed weekly starting at wk 1 postpartum for all cows. Overall, $76(28.5 \%)$ cows were anovular and $191(71.5 \%)$ were ovular by 71 DIM. Incidence of anovulation was not associated with level of milk production but was associated with lower body condition. For anovular cows $(n=41)$ that spontaneously recovered, the multiple ovulation rate at first ovulation was $46.3 \%$. For second and subsequent ovulations $(\mathrm{n}=463)$, the level of milk production for $14 \mathrm{~d}$ preceding estrus was associated with increased ovulation rate. To illustrate, incidence of multiple ovulations was $1.6 \%$ (2/128), 16.9\% (32/189), and $47.9 \%$ (70/146) for ovulations when cows were producing $<35,35$ to $<45$, and $\geq 45 \mathrm{~kg} / \mathrm{d}$, respectively. Among cows for which estrous behavior was recorded, those with multiple ovulations $(\mathrm{n}=48)$ had shorter duration of estrus $(4.3 \pm$ 0.7 vs. $9.9 \pm 0.5 \mathrm{~h})$ and higher production $(47.2 \pm 0.9$ vs. $38.1 \pm 0.5 \mathrm{~kg} / \mathrm{d}$ ) than cows with single ovulations $(\mathrm{n}=237)$. Circulating concentrations of estradiol were lower $(5.5 \pm 0.3 ; \mathrm{n}=15$ vs. $7.8 \pm 0.4 \mathrm{pg} / \mathrm{mL} ; \mathrm{n}=71)$ during periods of estrus with multiple ovulations despite a greater preovulatory follicular volume (4136 \pm 123 vs. $3085 \pm 110 \mathrm{~mm}^{3}$ ). Similarly, serum progesterone concentration $7 \mathrm{~d}$ after estrus was lower for cows with multiple than single ovulations ( $2.5 \pm 0.3$ vs. $3.2 \pm 0.1$ $\mathrm{ng} / \mathrm{mL})$ despite a greater luteal volume (8291 $\pm 516 \mathrm{vs}$.
\end{abstract}

Received November 5, 2004

Accepted April 5, 2005.

Corresponding author: M. C. Wiltbank; e-mail:wiltbank@wisc.edu.

*Trade names and names of commercial companies are used in this report to provide specific information. Mention of a trade name or manufacturer does not constitute a guarantee or warranty of the product by the USDA or an endorsement over products not mentioned. $\left.6405 \pm 158 \mathrm{~mm}^{3}\right)$. In summary, the first spontaneous ovulation in anovular cows and a higher level of milk production for $14 \mathrm{~d}$ preceding estrus were associated with increased multiple ovulation rate. Additionally, cows with multiple ovulations had lower estradiol at estrus, a shorter duration of estrus, and lower progesterone at $7 \mathrm{~d}$ after estrus than cows with single ovulations.

(Key words: dairy cow, multiple ovulation, milk production, anovulation)

Abbreviation key: $\mathbf{C L}=$ corpus luteum/corpora lutea, $\mathbf{E}_{2}=$ estradiol, $\mathbf{P}_{4}=$ progesterone.

\section{INTRODUCTION}

The process of selection of the dominant follicle during the ovulatory wave determines the ovulation rate in cattle. This process is characterized by a deviation in the growth rate between the largest (developing dominant) follicle and the smaller (subordinate) follicles of the wave, an event that has been termed diameter deviation (Ginther et al., 1997). Occasionally, the follicular selection process is altered and 2 or more follicles within a wave become dominant, resulting in a phenomenon termed codominance (Kulick et al., 2001). Because both codominant follicles have deviated from the subordinate follicles and acquired ovulatory capacity, they are responsive to ovulatory stimuli leading to the occurrence of multiple ovulations. If oocytes from such ovulations are fertilized and pregnancy is maintained until parturition, dizygotic twins will occur. One recent study that evaluated the frequency of monozygotic twins in dairy cattle by an evaluation of polymorphic microsatellite markers reported a frequency of monozygotic twins of $3.9 \%$ (Silva Del Rio et al., 2004). Thus, it appears that the frequency of monozygous twinning is low and, therefore, nearly all twins in dairy cattle are of the dizygotic type resulting from multiple ovulations.

Twinning in dairy cattle is undesirable because it reduces reproductive efficiency and profitability (Nielen et al., 1989; Day et al., 1995; Kinsel et al., 1998). Numerous factors are associated with twinning in dairy cattle including: age of dam, season, genetics, use of antibiot- 
ics or reproductive hormones, ovarian cysts, and peak milk production (reviewed in Wiltbank et al., 2000). Because of the current trend for increased milk yield in modern cows, there is growing concern about the association between milk production and twinning (Fricke, 2001). Interestingly, some studies (Nielen et al., 1989; Kinsel et al., 1998) but not others (Deluyker et al., 1991) have reported an association between those 2 factors.

Early studies evaluating the number of corpora lutea (CL) by rectal palpation reported multiple ovulation rates ranging from 5 to 13\% (Kidder et al., 1952; Labhsetwar et al., 1963). Unfortunately, the level of milk production was not reported in those studies. Nonetheless, recent studies with high-producing cows (35 to 45 kg/d; Fricke and Wiltbank, 1999; Santos et al., 2000; Sartori et al., 2004; López-Gatius et al., 2005) have reported greater multiple ovulation rates ranging from 14 to $39 \%$, suggesting an increase in this reproductive measure in modern cows.

The objective of this study was to evaluate factors associated with spontaneous multiple ovulation rate and anovulation in lactating dairy cows. In contrast to previous studies, this experiment used the average milk production near the time of ovulation (during the $14 \mathrm{~d}$ preceding estrus) to evaluate the association between milk yield and multiple ovulations.

\section{MATERIALS AND METHODS}

\section{Animals and Procedures}

A total of 267 cows (131 primiparous and 136 multiparous) were assigned at calving to this study. During the first 3 wk of lactation, cows were housed in a tie-stall barn and fed a transition diet ad libitum. Cows were subsequently moved to a free-stall barn where they were offered a balanced TMR ad libitum and remained during the experimental period. Cows were milked at 0500 and $1700 \mathrm{~h}$, and milk weights were recorded at each milking. All cows were administered bST (500 mg, Posilac; Monsanto Co., St. Louis, MO) every 2 wk, beginning at 60 to $66 \mathrm{DIM}$. The protocol used in this experiment was approved by the Animal Care Committee of the College of Agricultural and Life Sciences, University of Wisconsin, Madison.

Weekly transrectal ultrasonography was performed for all cows with a 7.5-MHz probe (Aloka 500 ultrasound machine; Corometrics Medical Systems Inc., Wallingford, CT) starting at 50 DIM and continuing until pregnancy was diagnosed ( $\sim 30 \mathrm{~d}$ post $\mathrm{AI})$. Ultrasound measurements of follicles and CL [length (L) and width (W)] were recorded from a single frozen image of the apparent maximal area of each structure and were used to calculate the volume (V). Follicular and CL volume were calculated with the formula $\mathrm{V}=4 / 3 \times \pi \times \mathrm{R}^{3}$ using a radius $(\mathrm{R})$ calculated by the formula $\mathrm{R}=(\mathrm{L} / 2+\mathrm{W} / 2) /$ 2. For CL with a fluid-filled cavity, the volume of the cavity was calculated and subtracted from the total CL volume. Multiple ovulation was retrospectively determined by presence of multiple CL and confirmed in most cows by presence of multiple dominant follicles in preovulatory ultrasound examinations. For cows with multiple preovulatory follicles and new CL after multiple ovulations, total follicular and luteal volumes were obtained by the addition of the volumes of the single corresponding structures.

Occurrence of the first ovulation postpartum was determined by analyses of serum progesterone $\left(\mathbf{P}_{4} ; \geq 1 \mathrm{ng} /\right.$ $\mathrm{mL}$ ) from blood samples collected weekly starting $1 \mathrm{wk}$ postpartum and continuing until cows were diagnosed pregnant or were 200 DIM. Anovulatory condition was defined by the absence of CL during the first 3 weekly ultrasound examinations after 50 DIM and by concentrations of serum $\mathrm{P}_{4}(<1 \mathrm{ng} / \mathrm{mL})$ from weekly samples. Cows that were anovular by 100 DIM received the Ovsynch protocol (Pursley et al., 1995) for synchronization of ovulation $(\mathrm{n}=35)$. Ovulations induced by this protocol were not included in the analyses for this study.

All cows were assigned a BCS once per month. Scoring was conducted by 3 individuals using a 5 -point scale with $1=$ very thin and $5=$ obese (Wildman et al., 1982), and the mean of the 3 scores was recorded. Body condition scoring was done for all cows on a given day; therefore, scores did not coincide with a selected day or week of lactation.

\section{Characterization of Estrous Behavior}

At 50 DIM, all cows were fitted with a pressure-sensitive radiotelemetric transmitter (HeatWatch, DDx Inc., Denver, CO) that allowed for continuous recording of standing activity. Activation of the transmitter by the weight of a mounting herdmate for a minimum of $2 \mathrm{~s}$ inhibits a radio-wave transmission, and generating real-time data (date, time, duration, cow number, and transmitter number). Onset of estrus was identified by the first activation of the transmitter. Duration of estrus was defined as the interval from the first to last standing event recorded during an estrous period; thus, periods of estrus consisting of only 1 standing event were excluded for this measure. All standing activity recorded by the radiotelemetry system was evaluated in relation to farm records for visual detection of estrus and AI, daily milk yield, and retrospective analyses of $\mathrm{P}_{4}$. Additionally, ovulation was confirmed for all periods of estrus by the appearance of a new CL during the ultrasound examination after standing activity was recorded by the radiotelemetry system. 


\section{Blood Collection and Radioimmunoassays}

Weekly blood samples were obtained from each cow via venipuncture of the median caudal vein starting 1 wk postpartum and continuing until a positive pregnancy diagnosis or 200 DIM for nonpregnant cows. Samples were placed immediately on ice and arrived at the laboratory within $8 \mathrm{~h}$ of collection. Blood samples were centrifuged $(3000 \times g$ for $15 \mathrm{~min})$ and serum was collected and stored at $-20^{\circ} \mathrm{C}$. Assay of $\mathrm{P}_{4}$ was performed using solid-phase radioimmunoassay kits (CoatA-Count Progesterone, DPC, Los Angeles, CA). Mean assay sensitivity, calculated as 2 SD below the mean counts per minute of maximum binding, was $0.02 \mathrm{ng} /$ $\mathrm{mL}$. Intra- and interassay coefficients of variation were 5.2 and $7.7 \%$, respectively.

Follicular size was recorded and serum estradiol $\left(\mathbf{E}_{\mathbf{2}}\right)$ concentrations were determined in a subset of cows on the day of estrus ( $\mathrm{n}=86 ; 61$ to $165 \mathrm{~d}$ postpartum) as determined by radiotelemetry. Blood samples for $\mathrm{E}_{2}$ were collected, processed, and stored as described above for $\mathrm{P}_{4}$ samples. A single assay of $\mathrm{E}_{2}$ was performed according to the procedure described by Kulick et al. (1999). Mean assay sensitivity, calculated as 2 SD below the mean counts per minute of maximum binding, was $0.4 \mathrm{pg} / \mathrm{mL}$. Intraassay coefficient of variation was $1.2 \%$.

\section{Statistical Analyses}

Evaluation of factors associated with the incidence of anovulation was performed by the LOGISTIC procedure of SAS (SAS Institute, 1998). The statistical model included cow, parity [treated as class with 2 levels (first and above first)], change in BCS between the closest scores recorded at 30 and $60 \mathrm{DIM}, \mathrm{BCS}$ closest to 60 DIM, average milk production during the first 70 DIM, and the average milk production from 50 to 70 DIM. Regression analysis was performed by the REG procedure of SAS (SAS Institute, 1996) to determine the best fitted line plot for the association between BCS closest to 60 DIM and the incidence of anovulation. Evaluation of the factors associated with multiple ovulations was performed by the MIXED procedure of SAS (Littell et al., 1996). For that analysis, the binomial distribution (macro GLIMMIX of SAS) was assumed for the response variable "number of ovulations" $(\mathrm{y}=0$ for single ovulation and $\mathrm{y}=1$ for more than 1 ovulation). The model included parity [treated as class with 2 levels (first and > first)], DIM, milk production during the 14 $\mathrm{d}$ preceding estrus, and cow, which was treated as a random effect. Additionally, the quadratic terms and interactions between main factors were included in this analysis. Using the estimates for the fixed effects and the $P$ values obtained in the logistic regression analysis, the probability of multiple ovulation $(\mathrm{y}=1)$ was calcu-

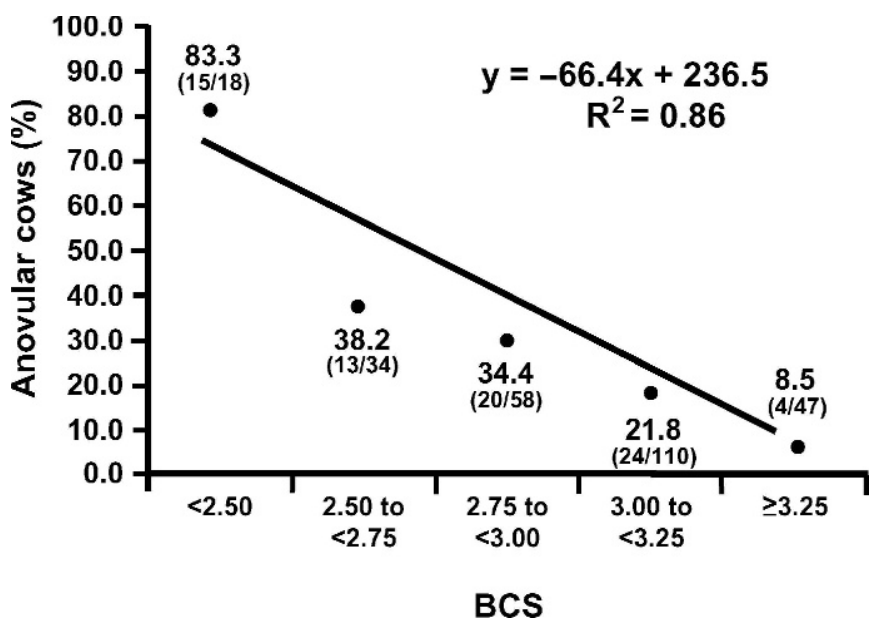

Figure 1. Negative linear relationship $(P<0.05)$ between BCS closest to $60 \mathrm{~d}$ postpartum and incidence of anovulation at $71 \mathrm{~d}$ postpartum.

lated by the formula $P=1 / 1+\mathrm{e}^{-\left(\mathrm{b}_{0}+\mathrm{b}_{1} \mathrm{x}_{1}+\mathrm{b}_{2} \mathrm{x}_{2}+\ldots+\right.}$ $b_{\mathrm{i}} \mathrm{X}_{\mathrm{i}}$. Duration of estrus, size of ovarian structures, concentrations of circulating $\mathrm{E}_{2}$ and $\mathrm{P}_{4}$, and milk production were compared between single and multiple ovulations by Student's $t$-test. The relationship between milk production and circulating $\mathrm{E}_{2}$ and $\mathrm{P}_{4}$, between milk production and follicular and CL volume, and between milk production and circulating $\mathrm{E}_{2}$ and $\mathrm{P}_{4}$ per unit volume of follicle and CL were analyzed by the REG procedure of SAS (SAS Institute, 1996). The statistical model included cow, DIM, and milk production during the 10 $\mathrm{d}$ preceding estrus for the evaluation of $\mathrm{E}_{2}$ and follicular volume and during the $7 \mathrm{~d}$ after estrus for the evaluation of $\mathrm{P}_{4}$ and luteal volume. The level of milk production from the $14 \mathrm{~d}$ before to the $14 \mathrm{~d}$ after estrus was evaluated for periods of estrus with single and multiple ovulations by the MIXED procedure of SAS (Littell et al., 1998; SAS Institute, 1998). Because some cows had more than 1 period of estrus recorded, the variable cow was introduced in the model as a random effect next to a fixed effect for periods of estrus with single and multiple ovulations. A probability of $P<0.05$ was defined as significant for this study.

\section{RESULTS AND DISCUSSION}

\section{Anovulation and First Postpartum Ovulation}

All 267 cows were included in the analyses of anovulation. Incidence of anovulation at 71 DIM was associated with a greater change in BCS between the closest scores recorded at 30 and 60 DIM $(P<0.005)$ and greater change in BCS between the scores closest to 30 and 60 DIM $(P<0.0001$; Figure 1$)$. In contrast, parity $(P=$ 


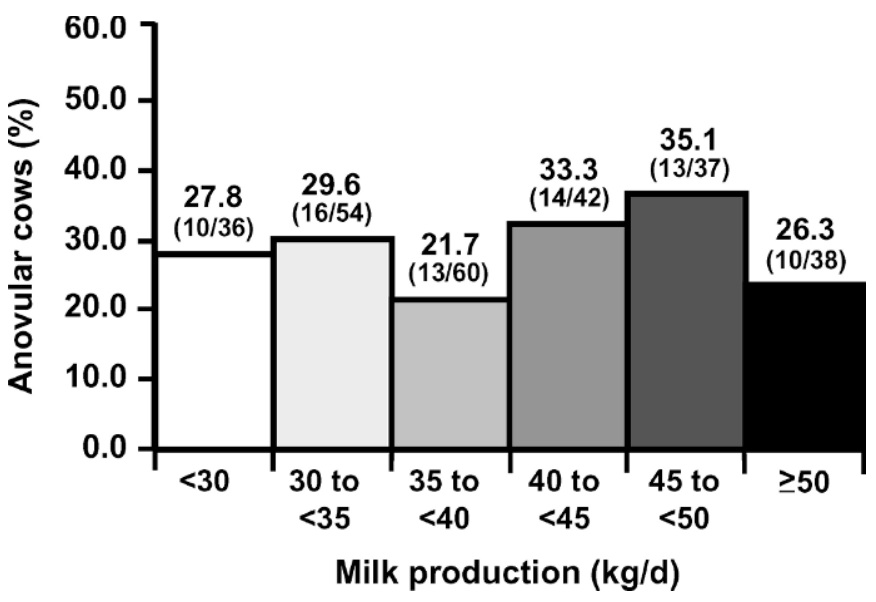

Figure 2. Incidence of anovulation at $71 \mathrm{~d}$ postpartum for cows assigned to milk production groups based on mean milk production from 50 to $70 \mathrm{~d}$ postpartum.

0.77 ), average milk production during the first 70 DIM $(P=0.65)$, and average milk production from 50 to 70 DIM $(P=0.72$; Figure 2$)$ were not associated with the incidence of anovulation at 71 DIM. Cows that lost BCS between 30 and 60 DIM had a greater incidence of anovulation by 71 DIM than cows that maintained or gained BCS during the same period [38.0 (38/100) vs. $22.8 \%$ (38/167); $P=0.008$ ] despite having similar milk production during the first 70 DIM ( $35.1 \pm 0.8$ vs. 36.6 $\pm 0.6 \mathrm{~kg} / \mathrm{d} ; P=0.16$ ). A linear relationship was found between BCS closest to 60 DIM and the incidence of anovulation at 71 DIM with the frequency of anovular cows decreasing as BCS increased (Figure 1). Similar to our results, Gümen et al. (2003) found a linear relationship between BCS at 47 to 53 DIM (range $\leq 2.25$ to $\geq 3.25$ ) and the incidence of anovulation by 53 DIM. However, Moreira et al. (2001) reported a quadratic effect of BCS at 60 DIM (range 2.0 to 4.5) and Santos et al. (2004) at 70 DIM (range 2.25 to 3.75 ) on the incidence of anovulation by 60 and 70 DIM, respectively. In the Santos study as in ours, a loss in BCS from 37 to 70 DIM, but not milk production during the first 3 mo of lactation, was associated with increased incidence of anovulation at 70 DIM. In spite of the strong association between lower BCS and delayed first postpartum ovulation, it is intriguing that at 71 DIM most [63.1\%; (48/76)] anovular cows had good BCS $(\geq 2.75)$. Similarly, in the study by Gümen et al. (2003), $62.5 \%(40 / 64)$ of the anovular cows at 60 DIM had BCS $\geq 2.75$. Those observations suggest that reasons other than low BCS might preclude most of the anovular cows from ovulating by 60 to 70 DIM.

The incidence of anovulation at 71 DIM did not differ between primiparous and multiparous cows [29.0\% (38/
$131)$ vs. $27.9 \%(38 / 136) ; P=0.84]$. The 2 parity groups had similar BCS closest to 60 DIM $(3.02 \pm 0.02$ for primiparous and $2.97 \pm 0.03$ for multiparous; $P=0.11$ ) even though multiparous cows produced more milk during the first 70 DIM $(41.5 \pm 0.6$ vs. $30.4 \pm 0.5 \mathrm{~kg} / \mathrm{d} ; P<$ $0.0001)$. A similar rate of anovulation in primiparous and multiparous cows differs from some reports (Gümen et al., 2003; Santos et al., 2004) but agrees with others (Cartmill et al., 2001; Bartolome et al., 2002). Unfortunately, BCS or milk production was not reported in the previous studies for primiparous and multiparous cows.

In the present study $53.9 \%(41 / 76)$ of the anovular cows at 71 DIM spontaneously recovered from the condition before 100 DIM. On average, those cows maintained or gained body condition between 60 and 100 DIM, whereas those cows that remained anovular were still losing condition during this period $(0.1 \pm 0.0$ vs. $-0.2 \pm 0.1$ BCS units; $P<0.001$ ). Nevertheless, milk production was similar from 70 to 100 DIM for cows that recovered and for those that were still anovular by $100 \mathrm{DIM}(41.9 \pm 1.1$ vs. $39.1 \pm 1.4 \mathrm{~kg} / \mathrm{d}$, respectively; $P=0.10)$.

Multiple ovulation rate was $46.3 \%$ (19/41) for first ovulations of cows that spontaneously recovered from the anovulatory condition between 70 and 100 DIM. No differences were detected in change in BCS between 60 and 100 DIM $(-0.1 \pm 0.1$ BCS units vs. $0.1 \pm 0.1 \mathrm{BCS}$ units; $P=0.16$ ) or in milk production from 70 to 100 DIM ( $42.8 \pm 1.7$ vs. $41.1 \pm 1.6 \mathrm{~kg} / \mathrm{d} ; P=0.45)$ between cows ovulating 1 or multiple follicles at first postpartum ovulation. Anovular cows that reached 100 DIM [46.1\% (35/76)] had ovulation synchronized (Ovsynch), and most of those cows [88.6\% (31/35)] had the first $\mathrm{P}_{4}$ increase detected by 125 DIM after they received Ovsynch.

\section{Multiple Ovulations in Cycling Cows}

For second and subsequent ovulations, multiple ovulation rate was $22.4 \%$ (104/463), and average milk production during the $14 \mathrm{~d}$ preceding estrus was $40.7 \pm 0.4$ $\mathrm{kg} / \mathrm{d}$. This multiple ovulation rate is within the range of 15 to $39 \%$ reported recently for high-producing lactating cows (35 to $45 \mathrm{~kg} / \mathrm{d}$; Santos et al., 2000; Sartori et al., 2004; López-Gatius et al., 2005). In our experiment, the level of milk production for the $14 \mathrm{~d}$ preceding estrus and DIM were associated with increased incidence of multiple ovulations. Figure 3 shows the actual incidence of multiple ovulations in relation to milk production. Additionally, a tendency for an interaction between the level of milk production during the $14 \mathrm{~d}$ preceding estrus and DIM $(P=0.07)$, and parity $(P=0.08)$ on increased incidence of multiple ovulation was de- 


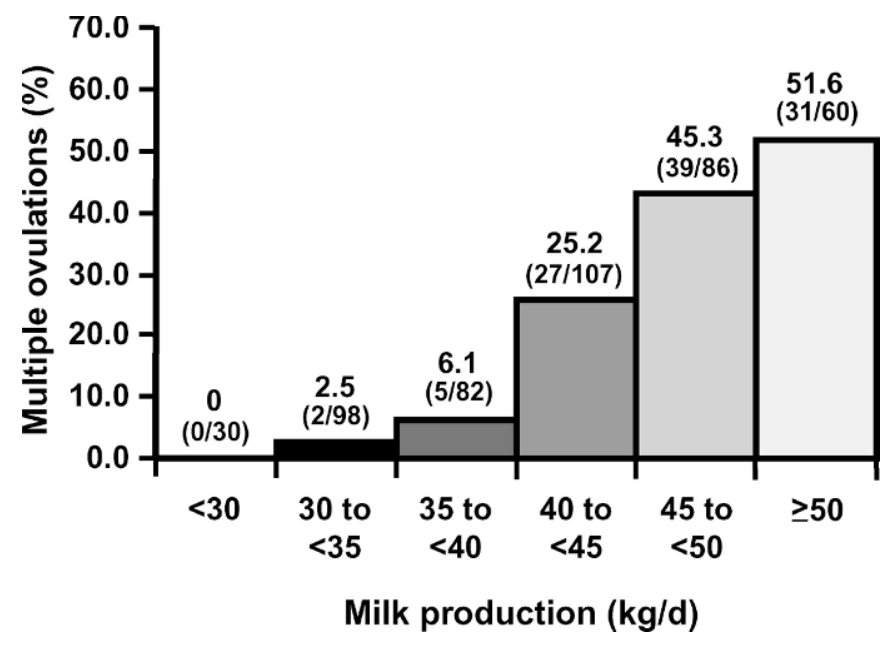

Figure 3. Incidence of multiple ovulations for cows assigned to milk production groups based on mean milk production during the $14 \mathrm{~d}$ preceding estrus.

tected. The estimates for the fixed effects and the corresponding $P$ values for the regression used to evaluate those associations were: intercept $(-49.13)$, parity $=1$ $(-0.96 ; P=0.08)$, DIM $(-0.16 ; P=0.0001)$, quadratic effect of DIM $(0.0004 ; P=0.002)$, average milk production for the $14 \mathrm{~d}$ before estrus $(2.18 ; P<0.0001)$, quadratic effect of average milk production for the $14 \mathrm{~d}$ before estrus $(-0.02 ; P<0.0001)$, and interaction between average milk production for the $14 \mathrm{~d}$ before estrus and DIM $(0.001 ; P=0.07)$. When those estimates were used to calculate the probability $(P)$ of multiple ovulation $(\mathrm{y}=1)$ by replacing them in the formula $P=1 / 1$

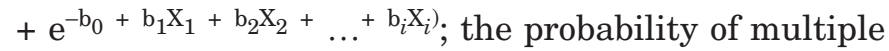
ovulation increased as the level of milk production during the $14 \mathrm{~d}$ preceding estrus increased (Figure 4). The

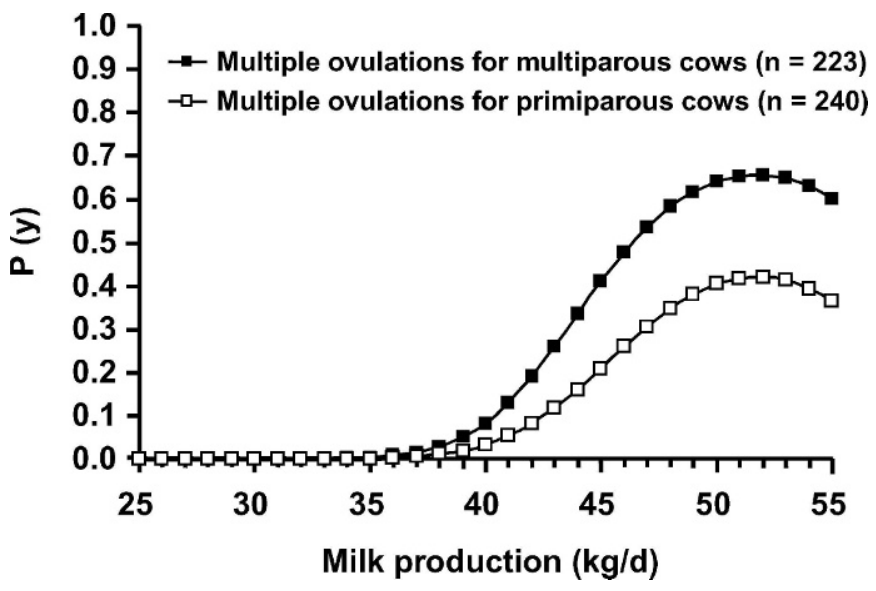

Figure 4. The relationship between the probability (y) of multiple ovulation and level of milk production during the $14 \mathrm{~d}$ preceding estrus. model for the probability of multiple ovulation is: $P(\mathrm{y})=$ $\mathrm{EXP}(-49.13)+\left(-0.96 \mathrm{X}_{1}\right)+\left(-0.16 \mathrm{X}_{2}\right)+\left(0.0004 \mathrm{X}_{3}\right)+$ $\left(2.18 \mathrm{X}_{4}\right)+\left(-0.02 \mathrm{X}_{5}\right)+\left(0.001 \mathrm{X}_{6}\right)$; where $\mathrm{X}_{1}=$ parity (first or above first), $\mathrm{X}_{2}=\mathrm{DIM}, \mathrm{X}_{3}=$ quadratic effect of DIM, $\mathrm{X}_{4}=$ average milk production for the $14 \mathrm{~d}$ before estrus, $\mathrm{X}_{5}=$ quadratic effect of average milk production for the $14 \mathrm{~d}$ before estrus, and $\mathrm{X}_{6}=$ interaction between average milk production for the $14 \mathrm{~d}$ before estrus and DIM.

Similar to the findings for this study, one experiment evaluating double ovulation rate in lactating cows that received Ovsynch reported a positive association between higher level of milk production and double ovulations (Fricke and Wiltbank, 1999). In that study, cows with greater than average milk production $2 \mathrm{~d}$ before timed AI ( $>40.0 \mathrm{~kg} / \mathrm{d} ; \mathrm{n}=94)$ had a greater incidence of double ovulation $(20.2$ vs. $6.9 \% ; P<0.05)$ than cows with less than average milk production $2 \mathrm{~d}$ before timed AI $(\leq 40.0 \mathrm{~kg} / \mathrm{d} ; \mathrm{n}=102)$. In contrast, another study evaluating multiple ovulation rate for synchronized and natural ovulations (López-Gatius et al., 2005) reported an antagonistic association between higher level of milk production and the incidence of multiple ovulations.

Several factors might explain the variation in the results from those studies. For example, first postpartum ovulations may have been included in the analyses, the cows had different levels of production [(40.5 \pm 0.8 kg/d) Fricke and Wiltbank, 1999; (35.6 \pm 9.7 kg) LópezGatius et al., 2005; $(40.7 \pm 0.4 \mathrm{~kg} / \mathrm{d})$ for the present study], and milk production data differed ( $2 \mathrm{~d}$ before AI: Fricke and Wiltbank, 1999; day of AI: López-Gatius et al., 2005; average of $14 \mathrm{~d}$ before estrus: present study). Based on the results discussed above, first postpartum ovulation is associated with an increased incidence of multiple ovulations that is unrelated to level of milk production. In addition, it appears that the dramatic increase in multiple ovulation rate occurs at levels of milk production above $40 \mathrm{~kg} / \mathrm{d}$, a level that may be achieved by relatively few cows in some studies. Further, the present (data presented below) and some previous studies (Lewis and Newman, 1984; Walton and King, 1986) show a reduction in milk production around the time of naturally occurring estrus that is not consistent between lower and higher producing cows. The effects of milk production on hormonal changes that cause selection of a single or multiple dominant follicles probably occur a few days before estrus when follicular deviation occurs (Lopez et al., 2005). Thus, future studies of multiple ovulation rate should consider using an average milk production during the few days before estrus/ovulation, use a complete regression analyses of the data because the relationship primarily is observed above $40 \mathrm{~kg} / \mathrm{d}$ of milk production, 
and should analyze first ovulation separate from other ovulations.

In contrast to the limited number of studies that have evaluated the association between milk production and ovulation rate, there is abundant evidence suggesting a positive relationship between higher milk yield and twinning rate (Nielen et al., 1989; Kinsel et al., 1998). One epidemiological study of twinning (Kinsel et al., 1998) using 52,362 lactations from 260 dairies from 1983 to 1992 reported that twinning rate increased steadily during the experimental period from 1.4 to $2.4 \%$ (range 0 to $9.6 \%$ ). In that study, cows calving twins had, on average, $2.7 \mathrm{~kg}$ greater peak milk production [33.9 $(\mathrm{n}=1276)$ vs. $31.2 \mathrm{~kg} / \mathrm{d}(\mathrm{n}=51,086)]$ than cows calving singletons.

Multiple ovulation rate [17.9 (43/240) vs. $27.3 \%$ (61/ 223); $P=0.01$ ] and milk production during the $14 \mathrm{~d}$ preceding estrus $(39.2 \pm 0.5$ vs. $42.0 \pm 0.5 \mathrm{~kg} / \mathrm{d} ; P<$ 0.0001 ) were lower for ovulations recorded from primiparous than multiparous cows. Additionally, a potential effect of parity $(P=0.08)$ was detected by the regression analysis evaluating factors associated with multiple ovulations. When average milk production during the $14 \mathrm{~d}$ preceding estrus was used to divide data into ovulations that occurred when milk production was higher or lower, multiple ovulation rate was greater $(P<0.001)$ for ovulations from high-producing primiparous [33.0\% (37/112); $46.0 \pm 0.4 \mathrm{~kg} / \mathrm{d}]$ and multiparous cows [41.1\% $(53 / 129) ; 47.6 \pm 0.3 \mathrm{~kg} / \mathrm{d}]$ than for ovulations from lowproducing primiparous [4.7\% (6/128); $33.3 \pm 0.3 \mathrm{~kg} / \mathrm{d}]$ and multiparous cows [8.5\% (8/94); $34.9 \pm 0.5 \mathrm{~kg} / \mathrm{d}]$.

Similarly, Fricke and Wiltbank (1999) reported that the incidence of double ovulation tended to increase $(P=0.09)$ with increasing parity. Additionally, in that study when cows were classified by average milk production $2 \mathrm{~d}$ before timed $\mathrm{AI}$ ( $\leq 40.0$ or $>40.0 \mathrm{~kg} / \mathrm{d}$ ), double ovulation rate was greater for primiparous $[22.2 \%(2 /$ 9)] and multiparous high producers [20.0\% (17/85)] than for primiparous [7.4\% (4/54)] and multiparous low producers [6.2\% (7/102)]. Likewise, López-Gatius et al. (2005) reported an increase in double ovulation with increasing parity from $6.7 \%$ (46/689) for first-lactation cows to $16.6 \%$ (89/536) for second-lactation cows, and to $25.0 \%(142 / 567)$ for third- or higher-lactation cows.

\section{Potential Mechanisms for Multiple Ovulations}

The mechanisms regulating ovulation rate under natural conditions are not defined in cattle. Nonetheless, some intriguing hormonal differences between single dominant and codominant heifers and cows have been reported. Kulick et al. (2001) found that heifers with codominant follicles had higher predeviation FSH, $\mathrm{LH}$, and $\mathrm{E}_{2}$ concentrations than heifers with a single dominant follicle. Lopez et al. (2005) found greater predeviation FSH and $\mathrm{LH}$, and lower inhibin and $\mathrm{P}_{4}$ in cows with codominant compared with single dominant follicles. Consistent with our current results, in this last study, cows with codominant follicles produced more milk than cows with single dominant follicles $(47.9 \pm 1.0$ vs. $37.8 \pm 0.7 \mathrm{~kg} / \mathrm{d})$. Results for these studies suggest that differences in the endocrine environment before deviation might play a role in the occurrence of codominance. Another common observation of studies evaluating follicular development and ovulation rate in cattle is the high incidence of codominance and multiple ovulations in animals that developed the ovulatory follicular wave in low or undetectable concentrations of $\mathrm{P}_{4}$. One study in beef heifers (Bailey et al., 2004) in which the ovulatory wave was synchronized to emerge and grow in the presence (high $\mathrm{P}_{4}$ ) or absence (low $\mathrm{P}_{4}$ ) of CL found multiple ovulation rates of 37.5 vs. $0 \%$ for waves that grew in the low vs. high $\mathrm{P}_{4}$ environment, respectively. Similarly, Matsui et al. (2004) reported incidences of codominance and multiple ovulations in both cows and heifers of 75 and $60 \%$, respectively, for waves that grew in a low $\mathrm{P}_{4}$ environment. Extending this concept to the current study, in cows that spontaneously recovered from the anovular condition and ovulated for the first time, the ovulatory wave likely grew in the absence of $\mathrm{P}_{4}$ and, this scenario could be the reason for the increased multiple ovulation rate observed in those cows.

A similar scenario could occur in cycling high-producing cows that also were found to have a reduction in circulating $\mathrm{P}_{4}$ (discussed below). This could be caused by increased metabolism of this hormone due to the increased feed consumption and liver blood flow associated with high milk production (Sangsritavong et al., 2002). A reduction in circulating $\mathrm{P}_{4}$ would be expected to increase $\mathrm{GnRH}$ and $\mathrm{LH}$ pulse frequency (Adams et al., 1992) and this could be the reason for the observed predeviation increase in $\mathrm{LH}$ reported in animals with codominant follicles (Kulick et al., 2001; Lopez et al., 2005). This increase in LH may be involved in the deviation mechanism because LH stimulates the production of $\mathrm{E}_{2}$ and insulin-like growth factor 1 (Ginther et al., 2001). These intrafollicular factors, among others, might increase responsiveness of the largest follicle(s) to the decreasing concentrations of FSH at deviation, thereby allowing more than 1 follicle to become dominant. The elevation in GnRH pulses may also increase circulating FSH before follicular deviation in a similar fashion to that observed in animals with codominant follicles (Kulick et al., 2001; Lopez et al., 2005). Alternatively, or in addition to the above hormonal changes, increases in growth hormone, either endogenous or exogenous, could also increase circulating IGF-I and this 
could have a role in increasing number of dominant follicles. Obviously, our study has highlighted the intriguing relationship between double ovulation rate and milk production but future intensive and manipulative studies will be needed to differentiate the numerous possible mechanisms that could be causing this relationship.

Thus, we would speculate that the absence of circulating $\mathrm{P}_{4}$ during development of the preovulatory wave in anovular cows might have allowed for an increase in predeviation LH concentrations, perhaps coupled with increased FSH, and this might have lead to an increased number of selected follicles and multiple ovulations. Similarly, lower circulating concentrations of $\mathrm{P}_{4}$ during development of the preovulatory wave in cows with high milk production might have allowed similar predeviation hormone alterations and this might have lead to an increased number of selected follicles and multiple ovulations in higher producing cows. Nevertheless, manipulative studies on the physiology of codominance in lactating dairy cows are required to validate these speculations.

\section{Duration of Estrus, Circulating Steroids, and Ovarian Structures in Multiple-Ovulating Cows}

Among cows for which estrous behavior was recorded, those with multiple ovulations $(\mathrm{n}=48)$ had shorter $(P$ $<0.0001)$ duration of estrus [4.3 $\pm 0.7(0.4$ to $19.2 \mathrm{~h})$ vs. $9.9 \pm 0.5 \mathrm{~h}(0.4$ to $26.5 \mathrm{~h})]$ and higher production $(47.2 \pm 0.9$ vs. $38.1 \pm 0.5 \mathrm{~kg} / \mathrm{d} ; P<0.001)$ than cows with single ovulations $(\mathrm{n}=237)$. Data on duration of estrus, ovarian structures, circulating hormones, and milk production associated with multiple and single ovulations for a subset of cows in which all this information was collected on the day of estrus and $7 \mathrm{~d}$ after estrus are included in Table 1. In this subset of cows, duration of estrus was also lower for cows with multiple compared with single ovulations, and circulating concentrations of $\mathrm{E}_{2}$ were lower for periods of estrus associated with multiple ovulations despite a greater preovulatory follicular volume. Similarly, 7 d later, serum $\mathrm{P}_{4}$ concentrations for cows with multiple ovulations were less than for cows with single ovulations despite a greater CL volume.

The poor correlation observed between ovarian structures and circulating hormones in this analysis might be caused by either a reduced production of $\mathrm{E}_{2}$ and $\mathrm{P}_{4}$ by the follicles and CL of the cows evaluated or by an increased metabolic clearance rate of these hormones leading to circulating concentrations that were less than expected. To our knowledge, no studies have validly evaluated whether follicles and CL of high-produc- ing lactating cows have lower $\mathrm{E}_{2}$ and $\mathrm{P}_{4}$ production than low-producing cows or heifers. Current evidence suggests that the low circulating concentrations of these hormones observed in high-producing cows might be caused by increased steroid metabolism associated with higher milk production and feed consumption (Sangsritavong et al., 2002).

Data from this study on single and multiple ovulations were used to evaluate the association between milk production and size of ovarian structures and circulating steroid hormones (Figure 5). Milk production during the $10 \mathrm{~d}$ preceding estrus and $7 \mathrm{~d}$ after the day of estrus was negatively related to circulating concentrations of $\mathrm{E}_{2}$ and $\mathrm{P}_{4}$, respectively (Figure $5 \mathrm{~A}$ and $\mathrm{B}$ ). Milk production during the $10 \mathrm{~d}$ preceding estrus was positively associated with follicular volume on the day of estrus (Figure 5C). Luteal volume was also positively correlated with milk production during the $7 \mathrm{~d}$ after estrus (Figure 5D). Multiple ovulators had some of the lowest circulating $\mathrm{E}_{2}$ and $\mathrm{P}_{4}$ concentrations despite having greater follicular and luteal volumes. We also analyzed the relationship between milk production vs. circulating concentrations of $\mathrm{E}_{2}$ and $\mathrm{P}_{4}$ by follicular and luteal unit volumes. This analysis showed the highest relationship with milk production $\left(\mathrm{R}^{2}=0.44\right.$ to 0.47$)$. Thus, these results are consistent with peak concentration of $\mathrm{E}_{2}\left(\right.$ or $\mathrm{P}_{4}$ ) and peak follicular or luteal volume being primarily related to milk production perhaps due to increasing steroid metabolism with increasing milk production. Surprisingly, circulating concentrations of $\mathrm{E}_{2}$ and $\mathrm{P}_{4}$ were not correlated with follicular volume on the day of estrus $(\mathrm{r}=-0.24 ; P=0.24)$ or with CL volume $7 \mathrm{~d}$ after estrus $(\mathrm{r}=-0.17 ; P=0.11)$, respectively. Duration of estrus was positively associated with circulating concentrations of $\mathrm{E}_{2}(\mathrm{r}=0.57 ; P<0.0001)$ but negatively associated with level of milk production during the $10 \mathrm{~d}$ before the day of estrus ( $\mathrm{r}=-0.60 ; P$ $<0.0001)$.

Previous authors have also reported a poor correlation between ovarian structures and circulating hormones in dairy cows with natural ovulations (Inbar et al., 2001; Sartori et al., 2002; Sartori et al., 2004). For example, Sartori et al. (2004) reported that lactating cows (single and double ovulators) despite having greater ovulatory size follicles than heifers had lower circulating $\mathrm{E}_{2}$ concentrations from luteolysis to ovulation. Similarly, $7 \mathrm{~d}$ after ovulation, $\mathrm{P}_{4}$ concentrations were lower in cows than heifers despite greater CL volume in cows. Differences in $\mathrm{P}_{4}$ persisted from $7 \mathrm{~d}$ after ovulation until luteolysis even though total CL volume was greater for cows during this period.

Therefore, results from the present and previous studies suggest that there is a poor correlation between 
Table 1. Milk production, duration of estrus, ovarian structures, and circulating hormones [mean \pm SEM (range)] for a subset of cows in which blood samples and ultrasonography of ovarian structures was conducted on the day of estrus and $7 \mathrm{~d}$ later.

\begin{tabular}{|c|c|c|c|}
\hline & $\begin{array}{l}\text { Multiple } \\
\text { ovulations } \\
\mathrm{n}=15\end{array}$ & $\begin{array}{l}\text { Single } \\
\text { ovulations } \\
\mathrm{n}=71\end{array}$ & $P$ value \\
\hline \multicolumn{4}{|l|}{ Day of estrus } \\
\hline Duration of estrus, ${ }^{1} \mathrm{~h}$ & $\begin{array}{l}4.0 \pm 1.0 \\
(0.4 \text { to } 15.7)\end{array}$ & $\begin{array}{l}9.8 \pm 0.9 \\
(0.4 \text { to } 26.5)\end{array}$ & 0.004 \\
\hline Follicular volume, ${ }^{2} \mathrm{~mm}^{3}$ & $\begin{array}{l}4136 \pm 123 \\
(3363 \text { to } 5198)\end{array}$ & $\begin{array}{l}3085 \pm 110 \\
(1436 \text { to } 6795)\end{array}$ & $<0.0001$ \\
\hline Estradiol, pg/mL & $\begin{array}{c}5.5 \pm 0.3 \\
(4.1 \text { to } 9.1)\end{array}$ & $\begin{array}{l}7.8 \pm 0.4 \\
(2.2 \text { to } 14.6)\end{array}$ & 0.005 \\
\hline Milk production, ${ }^{3} \mathrm{~kg} / \mathrm{d}$ & $\begin{array}{l}49.9 \pm 0.8 \\
(45.6 \text { to } 55.3)\end{array}$ & $\begin{array}{l}39.9 \pm 1.0 \\
(20.5 \text { to } 56.1)\end{array}$ & $<0.0001$ \\
\hline Days postpartum, ${ }^{4} \mathrm{~d}$ & $\begin{array}{l}90 \pm 8 \\
(61 \text { to } 165)\end{array}$ & $\begin{array}{l}97 \pm 3 \\
(61 \text { to } 157)\end{array}$ & 0.40 \\
\hline \multicolumn{4}{|l|}{ Seven days after estrus } \\
\hline Luteal volume, ${ }^{2} \mathrm{~mm}^{3}$ & $\begin{array}{l}8291 \pm 516 \\
(5198 \text { to } 12,370)\end{array}$ & $\begin{array}{l}6405 \pm 158 \\
(2144 \text { to } 8181)\end{array}$ & $<0.0001$ \\
\hline Progesterone, ng/mL & $\begin{array}{l}2.5 \pm 0.3 \\
(1.1 \text { to } 4.5)\end{array}$ & $\begin{array}{l}3.2 \pm 0.1 \\
(1.3 \text { to } 6.3)\end{array}$ & 0.04 \\
\hline Milk production, ${ }^{5} \mathrm{~kg}$ & $\begin{array}{l}49.3 \pm 0.5 \\
(45.5 \text { to } 55.2)\end{array}$ & $\begin{array}{l}38.5 \pm 0.4 \\
(18.9 \text { to } 57.0)\end{array}$ & $<0.0001$ \\
\hline
\end{tabular}

\footnotetext{
${ }^{1}$ Number of hours between the first and the last standing events of a period of estrus.

${ }^{2}$ Total follicular and luteal volumes were obtained by the addition of the volumes of the single corresponding structures.

${ }^{3}$ Average milk production for the $14 \mathrm{~d}$ preceding estrus.

${ }^{4}$ DIM when information on estrous behavior was collected by radiotelemetry.

${ }^{5}$ Average milk production for the $7 \mathrm{~d}$ after the day of estrus.
}

ovarian structures (follicle and CL) and circulating hormones $\left(\mathrm{E}_{2}\right.$ and $\left.\mathrm{P}_{4}\right)$ in high-producing cows and that this alteration might be caused by increased metabolism of those hormones during high milk production. Furthermore, such an alteration in circulating hormones might play an important role in the incidence of codominance and multiple ovulations.

\section{Milk Production at Estrus}

The level of milk production was evaluated from 14 $\mathrm{d}$ before to $14 \mathrm{~d}$ after estrus for second and subsequent ovulations. In general, multiple ovulations occurred during higher milk production than single ovulations $(47.5 \pm 0.2$ vs. $38.8 \pm 0.1 ; P<0.001)$. Single ovulations were further classified by the average milk production of the cow at the time of estrus as single ovulations occurring during higher $(\geq 38.8 \mathrm{~kg} / \mathrm{d})$ or lower milk production $(<38.8 \mathrm{~kg} / \mathrm{d})$. Milk production was greater $(P<$ 0.0001 ) for cows with multiple ovulations than for cows with single ovulations (Figure 6). In the same analysis, a reduction in milk production was observed around the time of estrus. To estimate this reduction, the difference between average milk production during the $10 \mathrm{~d}$ preceding estrus (used as a baseline) and milk production on the day of estrus was calculated for all periods of estrus. Overall, there was a reduction of $2.7 \pm 0.3 \mathrm{~kg}$ of milk $(6.4 \%)$ on the day of estrus. Interestingly, reduction in milk was less $(P<0.05)$ for periods of estrus associated with multiple ovulations [reduction $=1.6 \pm$ $0.5 \mathrm{~kg}(2.6 \%)]$ and single ovulations in cows producing $\geq 38.8 \mathrm{~kg} / \mathrm{d}$ [reduction $=2.4 \pm 0.4 \mathrm{~kg}(4.8 \%)$ ] than for periods of estrus associated with single ovulations for cows producing $<38.8 \mathrm{~kg} / \mathrm{d}$ [reduction $=3.5 \pm 0.4 \mathrm{~kg}$ $(9.6 \%)]$.

Previous studies have reported a reduction in milk production around the time of spontaneous estrus (Lewis and Newman, 1984; Walton and King, 1986) but no previous studies have evaluated the effect of milk yield or double ovulation on this reduction. This reduction might be caused by a decrease in feed intake (Walton and King, 1986) for cows in estrus because they spend less time feeding than herdmates not in estrus (Esslemont and Bryant, 1976). For example, Walton and King (1986) reported a decrease in milk yield (from 7 to more that $35 \%)$ and in feed intake $(>15 \%)$ on the day of estrus. For the present study, smaller reductions in milk production observed for periods of estrus occurring during higher milk production might be related to shorter and perhaps less intense expression of estrus due to reduced circulating concentrations of $\mathrm{E}_{2}$ in highproducing cows. Conversely, the greater reduction in 

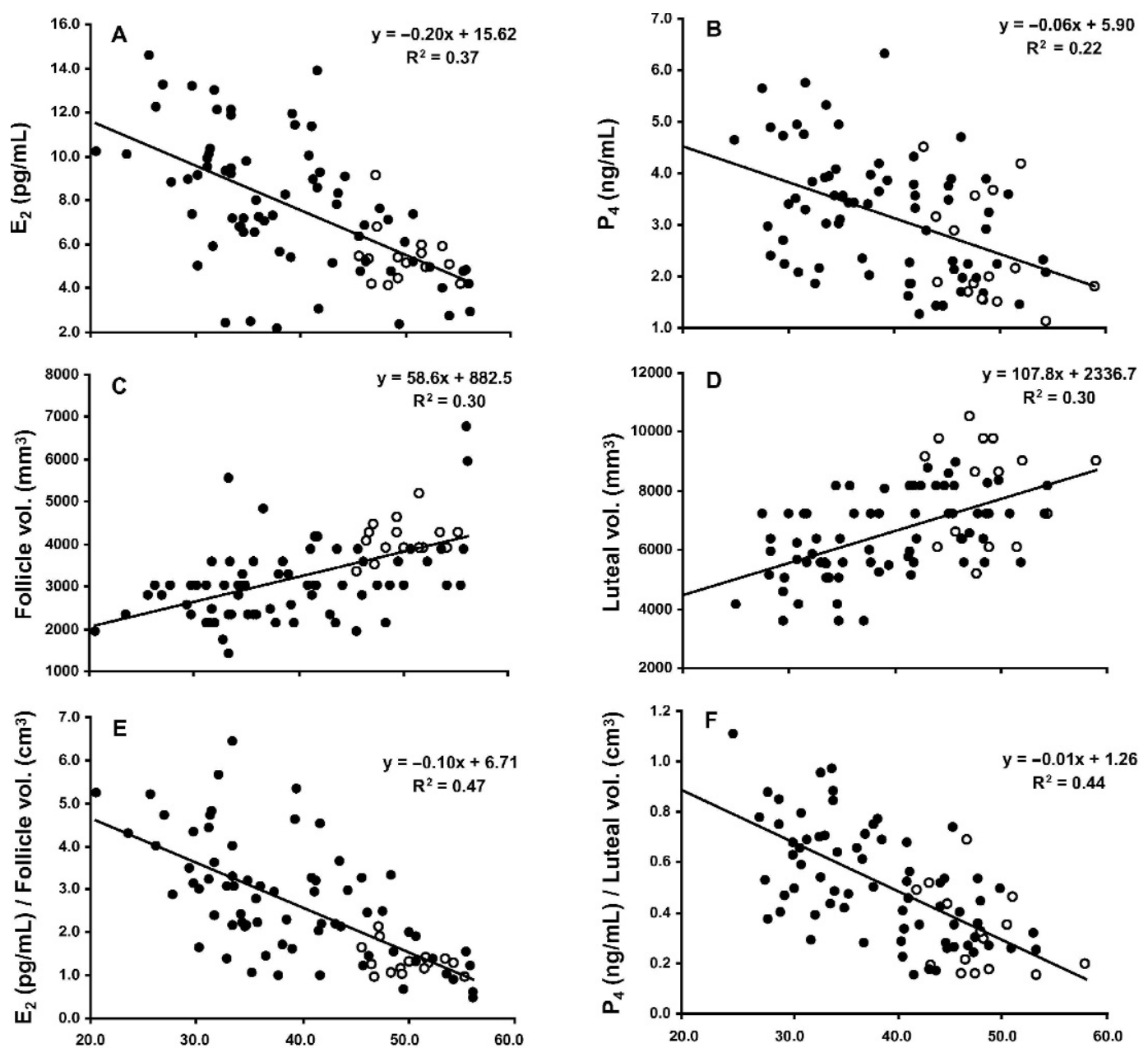

Milk production for the $10 \mathrm{~d}$ before estrus $(\mathrm{kg} / \mathrm{d})$

Milk production for the $7 \mathrm{~d}$ after estrus $(\mathrm{kg} / \mathrm{d})$

Figure 5. Relationship between circulating concentrations of estradiol $\left(\mathrm{E}_{2}\right)$ and progesterone $\left(\mathrm{P}_{4}\right)$ and the level of milk production $(\mathrm{A}$, $\mathrm{B})$, between follicular and luteal volume and the level of milk production $(\mathrm{C}, \mathrm{D})$, and between circulating concentrations of $\mathrm{E}_{2}$ and $\mathrm{P}_{4}$ by unit volume of follicle and corpus luteum (CL) and the level of milk production (E, F). Solid circles represent single ovulations (n = 71); open circles represent multiple ovulations $(\mathrm{n}=15)$. A linear relationship $(P<0.001)$ was identified for all analyses.

milk production observed for periods of estrus during lower production might be related to longer and perhaps more intense expression of estrus due to greater circulating concentrations of $\mathrm{E}_{2}$ in low-producing cows.

\section{CONCLUSIONS}

In summary, the first spontaneous ovulation occurring in anovular cows and a higher level of milk production for $14 \mathrm{~d}$ preceding estrus were associated with increased multiple ovulation rate. Results for this study might partially explain the increasing incidence of multiple ovulations and twinning currently observed in high-producing cows. Additionally, based on the association between higher milk production and multiple ovulation rate observed in this study, it might be ex- pected that twinning rates will continue to increase along with milk production in future years. Thus, research needs to be conducted to develop management strategies for improving the health and performance of periparturient twin-carrying cows or alternatively to modify the hormonal changes that are producing the increased multiple ovulation rate caused by high milk production.

\section{ACKNOWLEDGMENTS}

The authors wish to thank F. D. Kanitz and V. Moreira for assistance with data collection. Appreciation is extended to USDA-CREES National Research Initiative, Agricultural Systems research program (Grant \# 9703968) for partial funding of this study. 


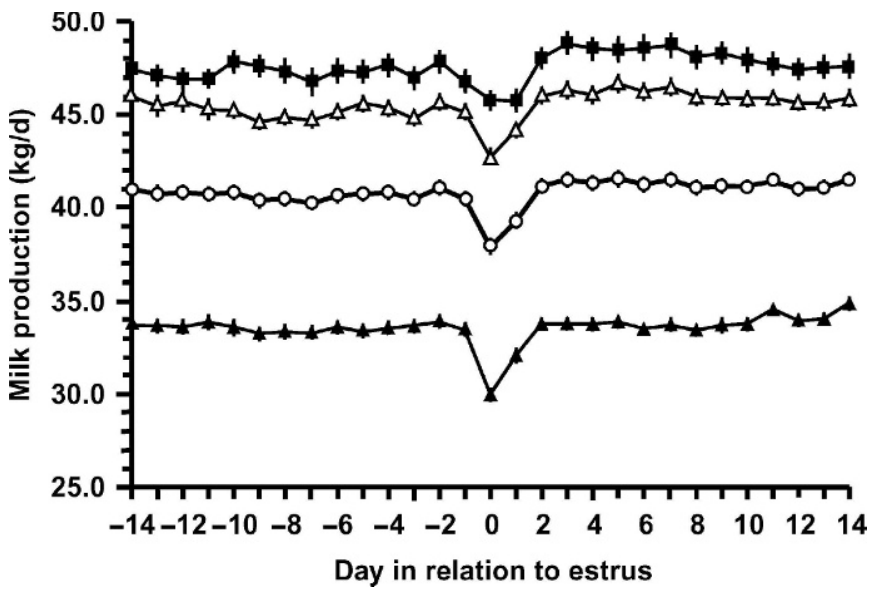

Figure 6. Mean $( \pm$ SEM) milk production of Holstein cows for 14 $\mathrm{d}$ before to $14 \mathrm{~d}$ after periods of estrus associated with multiple vs. single ovulations. Solid squares represent milk production for periods of estrus associated with multiple ovulations $(\mathrm{n}=104)$, open triangles represent milk production for periods of estrus with single ovulations during higher milk production $(\mathrm{n}=160)$, solid triangles represent milk production for periods of estrus associated with single ovulations during lower milk production $(\mathrm{n}=199)$, and open circles represent milk production associated with all ovulations.

\section{REFERENCES}

Adams, G. P., R. L. Matteri, and O. J. Ginther. 1992. Effect of progesterone on ovarian follicles, emergence of follicular waves and circulating follicle-stimulating hormone in heifers. J. Reprod. Fertil. 95:627-640.

Bailey, C. J., C. R. Burke, M. L. Mussard, and M. L. Day. 2004. Double ovulation following induction of luteal regression during ovarian follicular wave mergence in heifers. Presented at the American Dairy Science Association Midwest Section, Des Moines, IA.

Bartolome, J., J. Hernandez, A. Landaeta, A. Kelleman, P. Sheerin, C. A. Risco, and L. F. Archbald. 2002. The effect of interval from day of administration of bovine somatotropin (bST) to synchronization of ovulation and timed-insemination on conception rate of dairy cows with and without ovarian cysts. Theriogenology 57:1293-1301.

Cartmill, J. A., S. Z. El-Zarkouny, B. A. Hensley, G. C. Lamb, and J. S. Stevenson. 2001. Stage of cycle, incidents, and timing of ovulation, and pregnancy rates in dairy cattle after three timed breeding protocols. J. Dairy Sci. 84:1051-1059.

Day, J. D., L. D. Weaver, and C. E. Franti. 1995. Twin pregnancy diagnosis in Holstein cows: Discriminatory power and accuracy of diagnosis by transrectal palpation and outcome of twin pregnancies. Can. Vet. J. 36:93-97.

Deluyker, H. A., J. M. Gay, L. D. Weaver, and A. S. Azari. 1991. Change of milk yield with clinical diseases for a high producing dairy herd. J. Dairy Sci. 74:436-445.

Esslemont, R. J., and M. J. Bryant. 1976. Estrus behavior in a herd of dairy cows. Vet. Rec. 99:472-475.

Fricke, P. M. 2001. Review: Twinning in dairy cattle. Prof. Anim. Sci. 17:61-67.

Fricke, P. M., and M. C. Wiltbank. 1999. Effect of milk production on the incidence of double ovulation in dairy cows. Theriogenology 52:1133-1143.

Ginther, O. J., D. R. Bergfelt, M. A. Beg, and K. Kot. 2001. Follicle selection in cattle: Role of luteinizing hormone. Biol. Reprod. 64:197-205.

Ginther, O. J., K. Kot, L. J. Kulick, and M. C. Wiltbank. 1997. Emergence and deviation of follicles during the development of follicular waves in cattle. Theriogenology 48:75-87.
Gümen, A., J. N. Guenther, and M. C. Wiltbank. 2003. Follicular size and response to Ovsynch versus detection of estrus in anovular and ovular lactating dairy cows. J. Dairy Sci. 86:3184-3194.

Inbar, G., D. Wolfenson, Z. Roth, M. Kaim, A. Block, and R. BrawTal. 2001. Follicular dynamics and concentrations of steroids and gonadotropins in lactating cows and nulliparous heifers. J. Dairy Sci. 84(Suppl. 1):465. (Abstr.)

Kidder, H. E., G. R. Barrett, and L. E. Casida. 1952. A study of ovulations in six families of Holstein-Friesians. J. Dairy Sci. $35: 436-444$

Kinsel, M. L., W. E. Marsh, P. L. Ruegg, and W. G. Etherington. 1998. Risk factors for twinning in dairy cows. J. Dairy Sci. 81:989-993.

Kulick, L. J., D. R. Bergflet, K. Kot, and O. J. Ginther. 2001. Follicular selection in cattle: follicle deviation and codominance within sequential waves. Biol. Reprod. 65:839-846.

Kulick, L. J., K. Kot, M. C. Wiltbank, and O. J. Ginther. 1999. Follicular and hormonal dynamics during the first follicular waves in heifers. Theriogenology 52:913-921.

Labhsetwar, A. P., W. J. Tyler, and L. E. Casida. 1963. Analysis of variation in some factors affecting multiple ovulations in Holstein cattle. J. Dairy Sci. 46:840-842.

Lewis, G. S., and S. K. Newman. 1984. Changes throughout estrous cycles of variables that might indicate estrus in dairy cows. J. Dairy Sci. 67:146-152.

Littell, R. C., P. R. Henry, and C. B. Ammerman. 1998. Statistical analysis of repeat measures data using SAS procedures. J. Anim. Sci. 76:1216-1231.

Littell, R. C., G. A. Milliken, W. Stroup, and R. D. Wolfinger. 1996. SAS System for Mixed Models. SAS Institute, Inc., Cary, NC.

Lopez, H., R. Sartori, and M. C. Wiltbank. 2005. Reproductive hormones and follicular growth during development of one or multiple dominant follicles in cattle. Biol. Reprod. 72:788-795.

López-Gatius, F., M. López-Béjar, M. Fenech, and R. H. F. Hunter. 2005. Ovulation failure and double ovulation in dairy cattle: Risk factors and effects. Theriogenology 63:1298-1302.

Matsui, M., K. Hayashi, T. J. Acosta, B. C. Jayawardana, A. Sato, M. Ohtani, and A. Miyamoto. 2004. The absence of the corpus luteum induces co-dominant follicle during the first follicular wave in the cow. Page 200 (abstract 469) in Proc. Society for the Study of Reproduction meeting, Vancouver, BC, Canada.

Moreira, F., O. Orlandi, C. A. Risco, R. Mattos, F. Lopes, and W. W. Thatcher. 2001. Effects of presynchronization and bovine somatotropin on pregnancy rates to a timed artificial insemination protocol in lactating dairy cows. J. Dairy Sci. 84:1646-1659.

Nielen, M., Y. H. Schukken, D. T. Scholl, H. J. Wilbrink, and A. Brand. 1989. Twinning in dairy cattle: A study of risk factors and effects. Theriogenology 32:845-862.

Pursley, J. R., M. O. Mee, and M. C. Wiltbank. 1995. Synchronization of ovulation in dairy cows using $\mathrm{PGF}_{2 \alpha}$ and $\mathrm{GnRH}$. Theriogenology 44:915-923.

Sangsritavong, S., D. K. Combs, R. Sartori, L. Armentano, and M. C. Wiltbank. 2002. High feed intake increases liver blood flow and metabolism of progesterone and $17 \beta$-estradiol in dairy cows. J. Dairy Sci. 85:2831-2842.

Santos, J. E., J. T. Huber, C. B. Theurer, C. B. Nussio, L. G. Nussio, M. Tarazon, and D. Fish. 2000. Effects of grain processing and bovine somatotropin on metabolism and ovarian activity of dairy cows during early lactation. J. Dairy Sci. 83:1004-1015.

Santos, J. E., S. O. Juchem, R. L. Cerri, K. N. Galvao, R. C. Chebel, W. W. Thatcher, C. S. Dei, and C. R. Bilby. 2004. Effect of bST and reproductive management on reproductive performance of Holstein dairy cows. J. Dairy Sci. 87:868-881.

Sartori, R., J. M. Haughian, R. D. Shaver, G. J. Rosa, and M. C. Wiltbank. 2004. Comparison of ovarian function and circulating steroids in estrous cycles of Holstein heifers and lactating cows. J. Dairy Sci. 87:905-920.

Sartori, R., G. J. M. Rosa, and M. C. Wiltbank. 2002. Ovarian structures and circulating steroids in heifers and lactating cows in summer and lactating cows and dry cows in winter. J. Dairy Sci. 85:2813-2822.

SAS Institute. 1996. User's guide: Statistics, Version 6. SAS Institute, Inc., Cary, NC. 
SAS Institute. 1998. User's guide: Statistics, Version 7. SAS Institute, Inc., Cary, NC.

Silva Del Rio, N., B. W. Kirkpatrick, and P. M. Fricke. 2004. Observed frequency of monozygotic twinning in lactating Holstein cows. J. Dairy Sci. 87(Suppl. 1):65. (Abstr.)

Walton, J. S., and G. J. King. 1986. Indicators of estrus in Holstein cows housed in tie stalls. J. Dairy Sci. 69:2966-2973.
Wildman, E. E., G. M. Jones, P. E. Wagner, R. L. Boman, H. F. Troutt, and T. N. Lesch. 1982. A dairy cow body condition scoring system and its relationship to selected production characteristics. J. Dairy Sci. 65:495-501.

Wiltbank, M. C., P. M. Fricke, S. Sangsritavong, R. Sartori, and O. J. Ginther. 2000. Mechanisms that prevent and produce double ovulation in dairy cattle. J. Dairy Sci. 83:2998-3007. 